\title{
Entry of Heavy Metals into Food Chains: a 20-year Comparison Study in Northern Moravia (Czech Republic)
}

\author{
O. ČELECHOVSKÁ, L. MALOTA, S. ZIMA \\ Department of Biophysics and Biochemistry, Faculty of Veterinary Hygiene and Ecology, \\ University of Veterinary and Pharmaceutical Sciences, Brno, Czech Republic \\ Received February 1, 2008 \\ Accepted July 7, 2008
}

\begin{abstract}
Čelechovská O., L. Malota, S. Zima: Entry of Heavy Metals into Food Chains: a 20-year Comparison Study in Northern Moravia (Czech Republic). Acta Vet. Brno 2008, 77: 645-652.

The aim of the study presented here was to assess cadmium, lead and mercury contamination of wild-living animals and cattle in Northern Moravia (Czech Republic). Samples were collected in 2005-2007 at the same locations as in 1986-1989, in the same season of the year, and they were analyzed using the same methods (AAS). In 2005-2007, a significant decrease $(P<0.01)$ in cadmium concentrations in plant fodders was found, while changes in lead and mercury concentrations were less marked, and they depended on the type of commodity. In the 2005-2007 period, a marked decrease $(P<0.01)$ in cadmium concentrations in the muscle and kidneys of the cattle, fallow deer, roe deer and pheasants (muscle $0.002-0.009 \mathrm{mg} \cdot \mathrm{kg}^{-1}$, kidneys $0.11-0.69 \mathrm{mg} \cdot \mathrm{kg}^{-1}$ ) was found. In the same period, mercury concentrations in the muscle, liver and kidneys were significantly lower $(P$ $<0.01$ ) in cattle, roe deer and hare tissues (muscle: $0.6-3.5 \mu \mathrm{g}^{-1} \mathrm{~kg}^{-1}$, liver $3.3-41.0 \mu \mathrm{g} \cdot \mathrm{kg}^{-1}$, $\mathrm{kidney}^{-}$ $\left.16.3-43.2 \mu \mathrm{g} \cdot \mathrm{kg}^{-1}\right)$. Lower lead concentrations in the 2005-2007 period were only found in cows ( $0.04 \mathrm{mg} \cdot \mathrm{kg}^{-1}, 0.1 \mathrm{mg} \cdot \mathrm{kg}^{-1}$ and $0.6 \mathrm{mg} \cdot \mathrm{kg}^{-1}$ in muscle, liver and kidney samples, respectively). No significant differences in lead concentrations were found in the tissues of other animals.

The study demonstrated a reduction in the amounts of heavy metals entering food chains in the study area in recent years.
\end{abstract}

Cadmium, lead, mercury, muscle, liver, kidney, feedstuffs, AAS

Certain metals are an indispensable part of biomolecules, and one third of enzymes need metal ions for their catalytic activity. On the other hand, some metals have no natural biological function (e.g. cadmium, mercury and lead). When released to ecosystems, these metals accumulate in food chains and their toxic effects disrupt the existing biological balance (Beiglbock et al. 2002; Massanyi et al. 2000ab, 2005; Miadoková et al. 2000). Metals are introduced to ecosystems via natural routes and by anthropogenic processes. The greatest increase in toxic elements in the environment and the agrarian ecosystem was caused by the development of industry in the last century (Jones et al. 1987; Schulte-Rentrop et al. 2005). Beside immissions, the main reasons for increasing metal concentrations in the soil included the use of inorganic fertilizers, herbicides, pesticides and fungicides (Alloway et al. 1990; Mortvedt and Beaton 1995). Accumulation of heavy metals may block biochemical processes in soils and facilitate the entry of toxic metals into food chains (He et al. 2005). At the end of the last century, the entry of heavy metals into food chains was studied by a number of authors (e.g. Andersson and Bingefors 1985; Brams and Anthony 1985), who helped identify and eliminate possible sources of contamination, and monitored the effects on the flora and fauna (Yaaqub et al. 1991; Gnamus et al. 1995, 2000; Toman et al. 2005). These issues remain topical even today.

Northern Moravia (Czech Republic) is an area with marked industrial contamination (Hůnová 2003; Grodzinska 2003) and it came into focus when the issue of safe food production in an industrially contaminated area was studied in the 1980s (Zima et al. 1990). 
The aim of the present study was to determine present-day concentrations of cadmium, lead and mercury in selected plant materials from the same locality, and to compare heavy metal concentrations in cattle and wild animals with the situation of 20 years ago using the same analytical methods.

\section{Materials and Methods}

The studies were made in Northern Moravia (Czech Republic) on the Nový Jičín farm of the University of Veterinary and Pharmaceutical Sciences Brno in 1986-1989 and in 2005-2007 (Fig. 1). The research area included a game enclosure, i.e. a fenced-in area of 250 ha for the breeding of hooved game (marked as 1 and 2) and a hunting ground of 1,400 ha of agricultural land that included arable land (Nos 4, 5,6 and 9) and meadows and pastures (Nos 3, 7 and 8). Samples of soil, water, mineral fertilizers, plants and tissues of wild animals were taken at those sites. At animal production premises, samples of milk, animal feeds, supplementary feeds, drinking water and samples of tissues of slaughtered cows were taken. Between 1986 and 1989, over 1,200 samples were tested for cadmium, lead and mercury contamination. In 2005-2007 we analyzed 239 samples. Our study focussed specifically on those areas where elevated concentrations of the elements monitored were

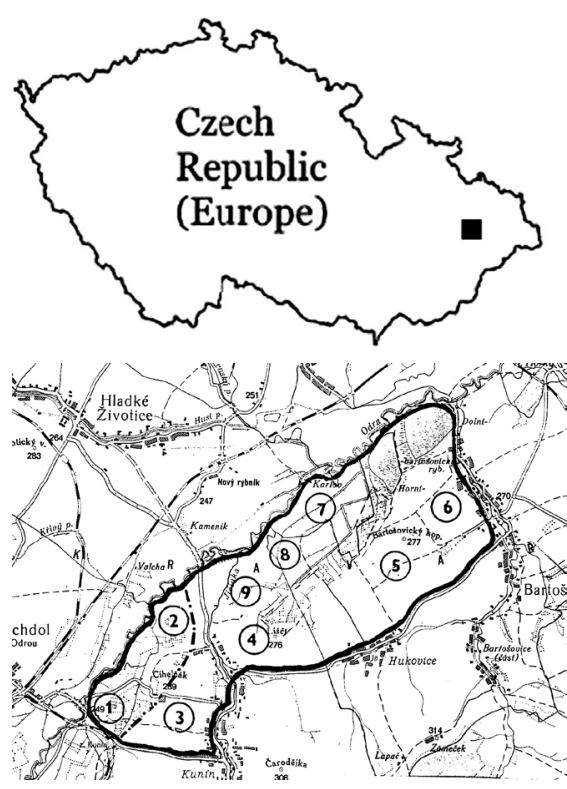

Fig. 1. Location of the research area $(1,2$ - deerforest; 4, 5, 6 and 9 - arable land; 3, 7 and 8 meadows and pastures). recorded. Samples were always collected at the following three intervals: I - first decade in May, II - third decade in July, III - first decade in October.

Soil

Soil samples were leached in hot nitric acid $\left(2 \mathrm{~mol} \cdot \mathrm{l}^{-1}\right)$. The leachates obtained were analyzed for the presence of $\mathrm{Cd}$ and $\mathrm{Pb}$ using flame AAS (Z-5000 spectrometer, Perkin Elmer, USA).

Mercury determination in all samples was performed on single-purpose mercury analyzers TMA-254 (detection limit $1 \mathrm{ng}$ ) and, in the 2005-2007 study, AMA-254 (detection limit $0.01 \mathrm{ng}$ ) manufactured by Altec s.r.o., (CR).

Tissues

Prior to $\mathrm{Cd}$ and $\mathrm{Pb}$ determination, dried-up samples of plant tissues and native samples of animal tissues ( $1 \mathrm{~g})$ were mineralized in laboratory autoclaves using nitric acid. In the 1980s traditional heating in the drying chamber was used. In the present study microwave heating was used instead (Ethos Sel, Milestone, Italy). Both in the 1980s and today, cadmium and lead were determined using atomic absorption spectrometry (AAS) with electrothermal atomization by a Z-5000 (Perkin Elmer, USA). Detection limits $(3 \sigma)$ for cadmium and lead in tissues were $1.25 \mu \mathrm{g} \cdot \mathrm{kg}^{-1}$ and $10 \mu \mathrm{g} \cdot \mathrm{kg}^{-1}$, respectively. In all cases, the procedures were verified using standard reference materials, specifically $\mathrm{H}-9$ and $\mathrm{V}-10$ (IAEA Vienna), 1577a NBS (USA) Nos 184, 185 and 186 (CRM Belgium) and Lucerne P-ALFALFA (Czechoslovak Metrologic Institute).

UNISTAT 5.1. software was used to statistically evaluate the metal concentrations found.

\section{Results and Discussion}

Soil

The selected study sites are characterized by the predominance of loamy to clayey soils. In 1986-1989, a total of 126 soil samples were examined. The ranges of cadmium, mercury and lead concentrations in soil were $0.29-0.6 \mathrm{mg} \cdot \mathrm{kg}^{-1}, 0.31-2.14 \mathrm{mg} \cdot \mathrm{kg}^{-1}$ and $17-31 \mathrm{mg} \cdot \mathrm{kg}^{-1}$, respectively. The analysis of mineral fertilizers used in 1986-1989 and of immission records from that period indicated a heavy contamination of the monitored countryside with hazardous metals, aggravated by acid precipitations $(\mathrm{pH}=4.9-5.6$ and Hg 0.4-1.0 $\mu \mathrm{g} \cdot \mathrm{l}^{-1}, \mathrm{~Pb} 9-29 \mu \mathrm{g} \cdot \mathrm{l}^{-1}$ and Cd 8-14 $\mu \mathrm{g} \cdot \mathrm{l}^{-1}$ ) (Zima et al. 1990).

In the present study, 20 soil samples were analyzed. A significant increase $(P<0.01)$ in soil cadmium concentrations (1986-1989: $0.32 \pm 0.10 ; 2005-2007: 0.88 \pm 0.24 \mathrm{mg} \cdot \mathrm{kg}^{-1}$ ) at sites 1 and 2 (game enclosure) was found. Most of the game enclosure area is not 
agriculturally managed land. It is an inundation area of the Odra river, and its floodwater and especially its sediments may account for the higher cadmium concentrations in the game enclosure soil. In the game enclosure area, a significant $(P<0.05)$ increase in soil $\mathrm{pH}(6.1 \pm 0.2 \rightarrow 6.7 \pm 0.3)$ was found as a result of intensive liming of the inundation area. There was only a small non-significant increase in $\mathrm{pH}$ at the remaining part of the area monitored $(6.4 \pm 0.3)$, with no significant differences in soil concentrations of the tested substances in individual time periods, which is in good agreement with literary data (Bergkvist et al. 2003; Makela-Kurtto and Sippola 2002; Wang et al. 1997).

Feedstuffs

Cadmium is an element with a high bioaccumulation index in the 1-10 range (Pais and Jones 1997). Cadmium concentrations (Fig. 2) in plant feedstuffs from individual sites in the 1980 s were significantly higher $(P<0.01)$, except for wheat shoots $(P<0.05)$, compared with the 2005-2007 period. Cadmium concentrations in plants depend on the plant species and the growth stage, and it is in correlation with cadmium concentration in the soil and the soil $\mathrm{pH}$, because high soil $\mathrm{pH}$ levels reduce cadmium availability for plants (Jones and Johnston 1989). This trend was particularly noticeable in the game reserve $(1,2)$.

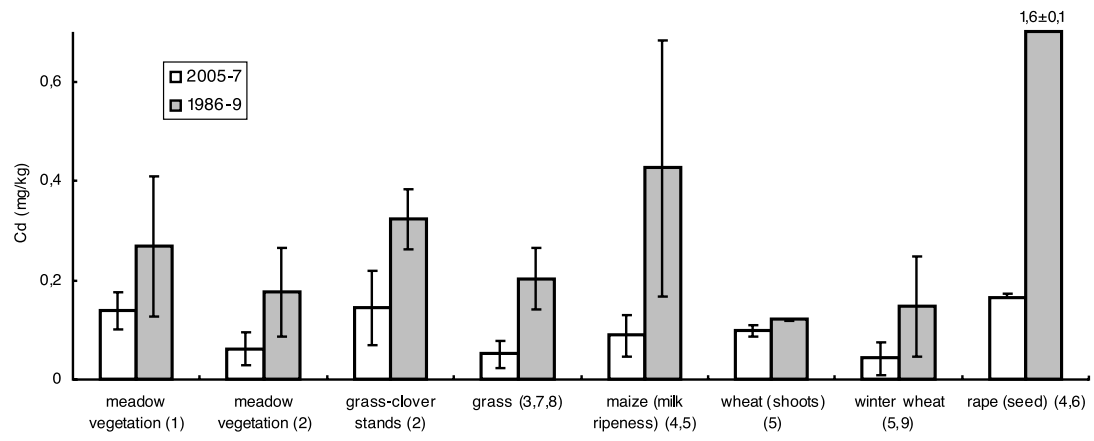

Fig. 2. Cadmium concentrations in plant feedstuffs (mean \pm SD)

Bioaccumulation index of lead is quite low $(0.01-0.1)$, and its entry into food chains depends largely on anthropogenic activities (Pais and Jones 1997). Although the amounts of lead released into the atmosphere have been reduced in recent decades (Harmens et al. 2004; Schulte-Rentrop et al. 2005), lead concentrations in meadow vegetations showed no significant decrease in 2005-2007, contrary to farm crops $(P<0.05)$ (Fig. 3). This may be due to the accumulation of lead in the topsoil of land with perennial stands.

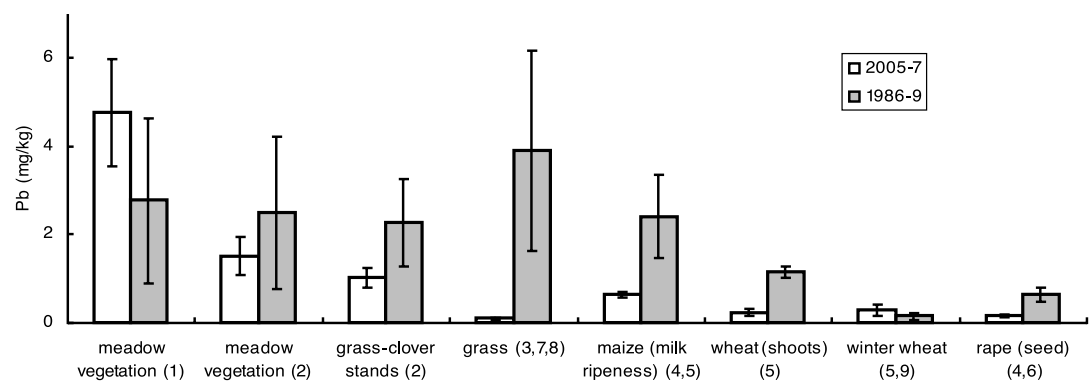

Fig. 3. Lead concentrations in plant feedstuffs (mean $\pm \mathrm{SD}$ ) 
In contrast to cadmium and lead concentrations, mercury concentrations in plant material (Fig. 4) showed no significant changes. A significant decrease in mercury concentrations was found only in winter wheat grain and oilseed rape seed. A slight increase, on the other hand, was found in meadow vegetation in the game enclosure. The mercury cycle is responsible for the steady state or even increasing levels of mercury in the environment (Dastoor and Larocque 2004; Houserová et al. 2006; Ryaboshapko et al. 2007).

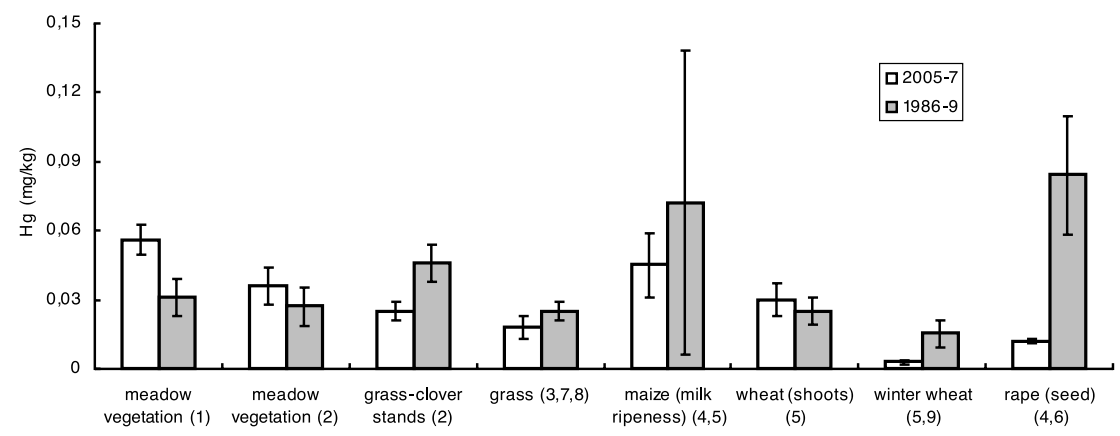

Fig. 4. Mercury concentrations in plant feedstuffs (mean \pm SD)

Animal tissues

Cadmium, lead and mercury concentrations in tissues of cows and wild animals are presented in Table 1. The age of wild animals from the 1986-1989 study was not accurately determined. All the animals were, however, at the age when they are usually harvested.

\section{Cadmium}

In both cows and wild animals, a significant $(P<0.01)$ decrease in cadmium concentrations compared with the 1986-1989 study was found in muscle tissues only. This is suggestive of lower cadmium intake levels at which the organism is still able to detoxicate and excrete the element rather than storing it in muscle tissue (Györi et al. 2005; Neathery et al. 1974). In both periods, cadmium concentrations in kidneys were higher $(P<0.01)$ than those in the muscle and liver $(P<0.05)$, and they are in good agreement with literature data (Gašparik et al. 2004). In hares, cadmium concentrations in the liver and kidneys were higher in the 2005-2007 period. That finding, however, is not relevant in view of the small number of samples examined in that period.

\section{Lead}

A significant decrease $(P<0.01)$ in lead concentrations in the muscle, liver and kidneys was found in cows. In wild animals, however, the trend was not significant, which was in line with levels found in meadow vegetation. Higher concentrations $(P<0.05)$ were found in the kidneys. In recent years, an increase has been recorded in drakes, but the results are not relevant because of the low number of samples examined.

\section{Mercury}

A significant decrease $(P<0.01)$ in concentrations of mercury in all the tissues examined (except for drakes) was found in comparison with the 1986-1989 study. In all the animals, mercury concentrations in kidneys were higher $(P<0.05)$ than mercury concentrations in muscle tissues in both monitoring periods.

Beside feedstuffs, drinking water was also examined. Concentrations of cadmium, lead and mercury in all water samples were very low and met the drinking water standards. Metal concentrations in milk were also below metal detection limits in both monitoring periods. 
Table 1. Concentrations of cadmium, lead and mercury in animal tissues

\begin{tabular}{|c|c|c|c|c|c|c|c|}
\hline Animal & Tissue & Year & $\mathrm{n}$ & $\begin{array}{c}\text { Age } \\
\text { (years) }\end{array}$ & $\begin{array}{l}\mathrm{Cd}\left(\mathrm{mg} \cdot \mathrm{kg}^{-1}\right) \\
\text { mean } \pm \mathrm{SD}\end{array}$ & $\begin{array}{c}\mathrm{Pb}\left(\mathrm{mg} \cdot \mathrm{kg}^{-1}\right) \\
\text { mean } \pm \mathrm{SD}\end{array}$ & $\begin{array}{r}\mathrm{Hg}\left(\mu \mathrm{g} \cdot \mathrm{kg}^{-1}\right) \\
\text { mean } \pm \mathrm{SD} \\
\end{array}$ \\
\hline \multirow[t]{6}{*}{ Cows } & muscle & $2005-7$ & 6 & $3-4$ & $0.004 \pm 0.001$ & $0.041 \pm 0.016$ & $1.1 \pm 1.0$ \\
\hline & & $1986-9$ & 6 & $3-4$ & $0.050 \pm 0.023$ & $0.253 \pm 0.039$ & $21.0 \pm 5.1$ \\
\hline & liver & $2005-7$ & 6 & & $0.095 \pm 0.029$ & $0.059 \pm 0.014$ & $3.3 \pm 0.7$ \\
\hline & & 1986-9 & 6 & & $0.084 \pm 0.016$ & $0.586 \pm 0.111$ & $24.3 \pm 4.5$ \\
\hline & kidneys & $2005-7$ & 6 & & $0.612 \pm 0.134$ & $0.072 \pm 0.030$ & $18.3 \pm 2.3$ \\
\hline & & $1986-9$ & 6 & & $0.728 \pm 0.204$ & $0.291 \pm 0.066$ & $51.0 \pm 9.4$ \\
\hline \multirow[t]{6}{*}{ Fallow deer } & muscle & $2005-7$ & 25 & $3.3 \pm 1.8$ & $0.006 \pm 0.004$ & $0.079 \pm 0.104$ & $0.6 \pm 0.3$ \\
\hline & & $1986-9$ & 3 & $3-4$ & $0.032 \pm 0.011$ & $0.095 \pm 0.062$ & \\
\hline & liver & $2005-7$ & 25 & & $0.069 \pm 0.152$ & $0.198 \pm 0.203$ & $3.0 \pm 2.2$ \\
\hline & & 1986-9 & 3 & & $0.120 \pm 0.031$ & $0.392 \pm 0.217$ & \\
\hline & kidneys & $2005-7$ & 25 & & $0.692 \pm 0.470$ & $0.124 \pm 0.172$ & $27.0 \pm 24.0$ \\
\hline & & $1986-9$ & 3 & & $0.655 \pm 0.302$ & $0.214 \pm 0.016$ & \\
\hline \multirow[t]{6}{*}{ Roe deer } & muscle & $2005-7$ & 7 & $2.7 \pm 0.2$ & $0.007 \pm 0.002$ & $0.099 \pm 0.022$ & $0.6 \pm 0.2$ \\
\hline & & 1986-9 & 14 & 3-4 & $0.045 \pm 0.038$ & $0.070 \pm 0.062$ & $11.1 \pm 6.7$ \\
\hline & liver & $2005-7$ & 7 & & $0.221 \pm 0.226$ & $0.060 \pm 0.033$ & $1.5 \pm 0.6$ \\
\hline & & $1986-9$ & 14 & & $0.278 \pm 0.141$ & $0.448 \pm 0.177$ & $5.0 \pm 2.0$ \\
\hline & kidneys & $2005-7$ & 7 & & $0.685 \pm 0.246$ & $0.160 \pm 0.159$ & $16.3 \pm 7.2$ \\
\hline & & 1986-9 & 14 & & $1.730 \pm 1.695$ & $0.308 \pm 0.258$ & $136.4 \pm 4.6$ \\
\hline \multirow[t]{2}{*}{ Drakes } & muscle & $2005-7$ & 2 & $3-4$ & $0.009 \pm 0.006$ & $0.140 \pm 0.077$ & $89.3 \pm 78.2$ \\
\hline & & 1986-9 & 8 & $3-4$ & $0.020 \pm 0.006$ & $0.028 \pm 0.009$ & $27.5 \pm 15.0$ \\
\hline \multirow[t]{4}{*}{ Pheasants } & muscle & $2005-7$ & 10 & $2-3$ & $0.003 \pm 0.001$ & $0.029 \pm 0.027$ & $1.5 \pm 0.9$ \\
\hline & & $1986-9$ & 23 & $2-3$ & $0.023 \pm 0.016$ & $0.050 \pm 0.012$ & $9.1 \pm 8.2$ \\
\hline & liver & $2005-7$ & 10 & & $0.033 \pm 0.008$ & $0.150 \pm 0.062$ & $6.2 \pm 4.4$ \\
\hline & kidneys & $2005-7$ & 10 & & $0.110 \pm 0.032$ & $1.204 \pm 0.182$ & $22.8 \pm 13.1$ \\
\hline \multirow[t]{6}{*}{ Hares } & muscle & $2005-7$ & 2 & $2-4$ & $0.002 \pm 0.001$ & $0.016 \pm 0.011$ & $3.5 \pm 0.5$ \\
\hline & & 1986-9 & 10 & $2-4$ & $0.020 \pm 0.008$ & $0.034 \pm 0.019$ & $12.8 \pm 9.1$ \\
\hline & liver & $2005-7$ & 2 & & $0.562 \pm 0.039$ & $0.092 \pm 0.015$ & $41.0 \pm 4.1$ \\
\hline & & 1986-9 & 5 & & $0.147 \pm 0.072$ & $0.284 \pm 0.083$ & $347 \pm 200$ \\
\hline & kidneys & $2005-7$ & 2 & & $8.84 \pm 2.00$ & $0.121 \pm 0.023$ & $43.2 \pm 4.2$ \\
\hline & & $1986-9$ & 5 & & $2.07 \pm 0.26$ & $0.204 \pm 0.094$ & $1466 \pm 319$ \\
\hline
\end{tabular}

Concentrations of cadmium, lead and mercury in hooved game found in 1986-1989 are in agreement with values found in 1987-1991 in Poland (Falandysz 1994). Preferential food items in the wild animals' diet may include plant species that have greater toxic metal accumulation capability, which may account for higher concentrations of those metals in some species of wild animals. Those species reflect the situation in the environment and are used as bioindicators (Gnamus et al. 2000; Kierdorf H and Kierdorf U 2000; Kottferová and Koréneková 2000; Frolich et al. 2001). Waterfowl migration over large areas and their feeding habits give a picture of the overall quality of the environment (Snively and Flaspohler 2006).

Mobility and bioavailability of metals is governed by a number of chemical and biochemical reactions, e.g. precipitation - solubility, adsorption - desorption, oxidation reduction and dissociation - complexation (Mortvedt and Beaton 1995; Wenzel et al. 
1999). Mobility of elements is also greatly affected by soil extract $\mathrm{pH}$ (Tlustoš et al. 1995; Öborn et al. 1995). An increasing $\mathrm{pH}$ greatly reduces the mobility of $\mathrm{Cd}$ and, partially also of $\mathrm{Pb}$. Although there was no demonstrable change in soil $\mathrm{pH}$ in the study area (with the exception of the game reserve), there was a reduction in the amounts of toxic metals entering the food chain. Another factor is the concentration of elements in individual layers of the soil. In uncultivated land, complex-forming elements remain in upper layers and metal concentrations on the surface increase due to immissions (He et al. 2005; Sichorová et al. 2004).

Concentrations of cadmium, lead and mercury found in animal tissue samples taken in 2005-2007 are low and represent no health risk for consumers. The findings reflect improvements in the quality of the environment not limited only to the Czech Republic (Hůnová 2003; Wang 1997), and also the integration of research results in agricultural practice. The result is a decreasing trend of risk elements entry into the food chain.

\section{Vstup těžkých kovů do potravních řetězců: porovnání po 20 letech na území severní Moravy}

Cílem předkládané práce bylo posouzení zátěže (kontaminace) volně žijící zvěře a skotu kadmiem, olovem a rtutí na území severní Moravy. Vzorky byly sbírány v letech 2005-2007 na stejných lokalitách jako v roce 1986-1989, ve stejném ročním období a analyzovány shodnými metodami (AAS). V letech 2005-2007 bylo zjištěno statisticky průkazné snížení $(P<0,01)$ obsahu kadmia $\mathrm{v}$ rostlinných krmivech, změna u olova a rtuti nebyla tak výrazná a byla odvislá od druhu komodity. Výrazné snížení $(P<0,01)$ koncentrace kadmia ve svalovině a ledvinách bylo zjištěno u skotu, daňků, srnců a bažantů v letech 2005-2007 (svalovina 0,002-0,009 $\mathrm{mg} \cdot \mathrm{kg}^{-1}$, ledviny $0,11-0,69 \mathrm{mg} \cdot \mathrm{kg}^{-1}$ ). Koncentrace rtuti ve svalovině, játrech a ledvinách byla signifikantně nižší $(P<0,01)$ u tkání skotu, srnců a zajíců v letech 2005-2007 (svalovina: 0,6-3,5 $\mu \mathrm{g} \cdot \mathrm{kg}^{-1}$, játra 3,3-41,0 $\mu \mathrm{g} \cdot \mathrm{kg}^{-1}$, ledviny 16,3-43,2 $\mu \mathrm{g} \cdot \mathrm{kg}^{-1}$ ). Snížené koncentrace olova ve tkáních v období 2005-2007 bylo zjištěno pouze u krav (svalovina 0,04 , játra 0,1 a ledviny $0,6 \mathrm{mg} \cdot \mathrm{kg}^{-1}$ ), tkáně ostatních zviŕat nevykazovaly signifikantní změny.

Výzkum prokázal snižený vstup těžkých kovů do potravních řetězců na sledovaném území v posledních letech.

\section{Acknowledgement}

The authors are very grateful to Mr František Vitula for his assistance in collecting tissue samples of the game harvested.

This study was supported by the Project MSM 6215712402 of the Ministry of Education, Youth and Sports of the Czech Republic.

\section{References}

ALLOWAY BJ, JACKSON AP, MORGAN H 1990: The accumulation of cadmium by vegetables grown on soils contaminated from a variety of sources. Sci Total Environ 91: 223-236

ANDERSSON A, BINGEFORS S 1985: Trends and annual variations in cadmium concentration in grain of winter wheat. Acta Agric Scand Sect B-Soil Plant Sci 35: 339-344

BEIGLBOCK C, STEINECK T, TATARUCH F, RUF T 2002: Environmental cadmium induces histopathological changes in kidneys of roe deer. Environ Toxicol Chem 21: 1811-1816

BERGKVIST P, JARVIS N, BERGGREN D, CARLGREN K 2003: Long-term effect of sewage sludge applications on soil properties, cadmium availability and distribution in arable soil. Agric Ecosyst Environ 97: $167-179$

BRAMS E, ANTHONY W 1985: Biological monitoring of an agricultural food-chain-soil trace metals in ruminant tissues. Abstr Pap Am Chem Soc 190: 25

DASTOOR AP, LAROCQUE Y 2004: Global circulation of atmospheric mercury: a modelling study. Atmos Environ 38: 147-161

FALANDYSZ J 1994: Some toxic and trace metals in big game hunted in the northern part of Poland in 1987-1991. Sci Total Environ 141: 59-73 
FROLICH K, STEINBACH F, KLIMA F, TATARUCH F, STREICH J, WISSER J, ACHAZI R 2001: Characterisation of health status parameters in roe deer from highly polluted areas (cadmium, lead, organochlorines) compared with areas of low pollution. Z Jagdwiss 47: 125-144

GAŠPARIK J, MASSANYI P, SLAMEČKA J, FABIŠ M, JURČIK R 2004: Concentration of selected metals in liver, kidney, and muscle of the red deer (Cervus elaphus). J Environ Sci Health Part A- Toxic/Hazard Subst Environ Eng 39: 2105-2111

GNAMUS A, HORVAT M, STEGNAR P 1995: The mercury content among deer and of browsed foliage as a means of ascertaining environmental-pollution of the mining regions Idrija - a case-study from Slovenia. Z Jagdwiss 41: 198-208

GNAMUS A, BYRNE, AR, HORVAT M 2000: Mercury in the soil-plant-deer-predator food chain of a temperate forest in Slovenia. Environ Sci Technol 34: 3337-3345

GRODZINSKA K, FRONTASYEVA M, SZAREK-LUKASZEWSKA G, KLICH M, KUCHARSKA-FABIS A, GUNDORINA SF, OSTROVNAYA TM 2003: Trace element contamination in industrial regions of Poland studied by moss monitoring. Environ Monit Assess 87: 255-270

GYŐRI Z, KOVÁCS B, DANIELS P, SZABO P, PHILLIPS C 2005: Cadmium and lead in Hungarian porcine products and tissues. J Sci Food Agric 85: 1049-1054

HARMENS H, BUSE A, BUKER P, NORRIS D, MILLS G, WILLIAMS B, REYNOLDS B, ASHENDEN TW, RUHLING A, STEINNES E 2004: Heavy metal concentrations in European mosses: 2000/2001 survey. J Atmos Chem 49: 425-436

HE ZL, YANG XE, STOFFELLA PJ 2005: Trace elements in agroecosystems and impacts on the environment. J Trace Elem Med Biol 19: 125-140

HOUSEROVÁ P, JANÁK K, KUBÁŇ P, PAVLÍČKOVÁ J, KUBÁŇ V 2006: Chemical forms of mercury in aquatic ecosystems - properties, levels, cycle and determination. Chem Listy 100: 862-876

HŮNOVÁ I 2003: Ambient air quality for the territory of the Czech Republic in 1996-1999 expressed by three essential factors. Sci Total Environ 303: 245-251

JONES KC, JOHNSTON AE 1989: Cadmium in cereal grain and herbage from long-term experimental plots at Rothamsted, UK. Environ Pollut 57: 199-216

JONES KC, SYMON CJ, JOHNSTON AE 1987: Retrospective analysis of an archived soil collection. II. Cadmium. Sci Total Environ 67: 75-89

KIERDORF H, KIERDORF U 2000: Roe deer antlers as monitoring units for assessing temporal changes in environmental pollution by fluoride and lead in a German forest area over a 67-year period. Arch Environ Contam Toxicol 39: 1-6

KOTTFEROVÁ J, KORÉNEKOVÁ B 2000: Game as an indicator of environmental pollution by cadmium and lead. J Trace Microprobe Tech 18: 571-575

MAKELA-KURTTO R, SIPPOLA J 2002: Monitoring of Finnish arable land: changes in soil quality between 1987 and 1998. Agr Food Sci Finl 11: 273-284

MASSANYIP, TRANDZIK J, STRAPAK P, KOVÁČIK J, SIMO K, LUKAČ N, TOMAN R 2000a: Contamination of bovine insemination doses with cadmium, copper, lead and zinc and its relation to semen activity. J Environ Sci Health Part A-Toxicol/Hazard Subst Environ Eng 35: 1637-1644

MASSANYI P, UHRÍN V, SIROTKIN AV, PAKSY K, FORGÁCS ZS, TOMAN R, KOVÁČIK J 2000b: Effects of cadmium on ultrastructure and steroidogenesis in cultured porcine ovarian granulosa cells. Acta Vet Brno 69: 101-106

MASSANYI P, UHRÍN V, TOMAN R, PIVKO J, LUKAČ N, FORGÁCS ZS, SOMOSY Z, FABIŠ M, DANKO J 2005: Ultrastructural changes of ovaries in rabbits following cadmium administration. Acta Vet Brno 74: 29-35

MIADOKOVÁ E, VLČKOVÁ V, JENDRAŠŠKOVÁ N, VLČEK D, ŠUCHA V 2000: Mutagenic and comutagenic effects of acid-mine water containing heavy metals. J Trace Microprobe Tech 18: 201-207

MORTVEDT JJ, BEATON JD 1995: Heavy metal and radionuclide contaminants in phosphate fertilizers. In: TIESSEN H (Ed.): Phosphorus in the global environment: transfer, cycles and management. Wiley, New York, pp. 93-106

NEATHERY MW, MILLER WJ, GENTRY RP, STAKE PE, BLACKMON DM 1974: Cadmium-109 and methyl mercury-203 metabolism, tissue distribution, and secretion into milk of cows. J Dairy Sci 57: 1177-1183

ÖBORN I, JANSSON G, JOHNSSON L 1995: A field study of soil pH on trace element levels in spring wheat, potatoes and carrots. Water Air Soil Pollut 85: 835-840

PAIS I, JONES JB Jr. 1997: Handbook of Trace Elements. St. Lucie Press, Boca Raton, Florida, USA, 223 p.

RYABOSHAPKO A, BULLOCK OR Jr., CHRISTENSEN J, COHEN M, DASTOOR A, ILYIN I, PETERSEN G, SYRAKOV D, TRAVNIKOV O, ARTZ RS, DAVIGNON D, DRAXLER RR, MUNTHE J, PACYNA J 2007: Intercomparison study of atmospheric mercury models: 2. Modelling results vs. long-term observations and comparison of country deposition budgets. Sci Total Environ 377: 319-333

SICHOROVÁ K, TLUSTOŚ P, SZÁKOVÁ J, KOŘÍNEK K, BALÍK J 2004: Horizontal and vertical variability of heavy metals in the soil of a polluted area. Plant Soil Environ 50: 525-534

SCHULTE-RENTROP A, COSTA-CABRAL M, VINK R 2005: Modelling the overland transport of lead deposited from atmosphere in the Elbe catchment over four decades (1958-1995). Water Air Soil Pollut 160: 271-291 
SNIVELY M, FLASPOHLER D 2006: A comparative study of cadmium and copper in ruffed grouse (Bonasa umbellus) in regions with and without historic mining. Ecotox Environ Safe 65:165-170

TLUSTOŠ P, VOSTÁL J, SZÁKOVÁ J, BALÍK J 1995: Direct and subsequent efficiency of selected measures on the $\mathrm{Cd}$ and $\mathrm{Zn}$ content in the biomass of spinach. Rostl Vyr 41: 31-37

TOMAN R, MASSANYI P, LUKAČ N, DUCSAY L, GOLIAN J 2005: Fertility and content of cadmium in pheasant (Phasianus colchicus) following cadmium intake in drinking water. Ecotox Environ Safe 62: $112-117$

WANG Y, THORNTON I, FARAGO M 1997: Changes in lead concentrations in the home environment in Birmingham, England over the period 1984-1996. Sci Total Environ 207: 149-156

WENZEL WW, LOMBI E, ADRIANO DC 1999: Biogeochemical processes in the rhizosphere: role in phytoremediation of metal-polluted soils. In: PRASAD M, HAGEMEYER J (Eds.): Heavy metal stress in plants: from biomolecules to ecosystems. Springer-Verlag, Berlin, pp. 273-303

YAAQUB RR, DAVIES TD, JICKELLS TD, MILLER JM 1991: Trace elements in daily collected aerosols at a site in south-eastern England. Atmos Environ 25: 985-996

ZIMA S, ZABLOUDIL F, ČELECHOVSKÁ O, MALOTA L 1990: Frequency of occurence of risk elements in food chain. (Frekvence výskytu rizikových prvků v potravinovém retězci.). Univ Vet Med Brno, 99 pp. (Research report - project no. 9.3 ŠZP Nový Jičín, 1986 - 1990) (In Czech) 